Revista Iberoamericana. Vol. LXIII, Núm. 180, Julio-Setiembre 1997; 467-484

\title{
ROA BASTOS Y EL "NAPOLEÓN DEL PLATA" UNA FASCINACIÓN NOVELESCA EN TRES ETAPAS
}

POR

Aldo Albònico

Universidad de Milán

Es bien conocida la recreación del Doctor José Gaspar Rodríguez de Francia que llevó a cabo Augusto Roa Bastos en Yo el Supremo. Esta ingente labor se anunciaba ya, en cierta medida, en otros escritos narrativos del autor en los cuales el que fue dictador del Paraguay entre 1814 y 1840 empezaba a asomarse: las más interesantes de estas apariciones anticipatorias son las incluidas en el cuento juvenil "Lucha hasta el alba"' y en el primer capítulo de la conocida novela Hijo de hombre. ${ }^{2}$

Sin llegar al punto de dedicarle al tema una novela entera, bastante análogo resulta el tratamiento que Roa Bastos ha reservado a otra gran figura de la historia del Paraguay independiente del siglo XIX.

Hay que recordar que, muerto el Doctor Francia, el país llegó a ser por casi treinta años el coto cerrado de una sola familia. Carlos Antonio López - primero cónsul y luego, desde 1844, presidente dentro de un marco constitucional que le daba poderes amplísimos y no permitía de facto oposición alguna- modernizó el Estado técnica y económicamente. A su muerte, en 1862, le sucedió su hijo Francisco Solano, nacido en 1827: hombre de amplia cultura pero muy aficionado a las armas y deseoso de tener en Sudamérica el mismo papel que en Europa tenía Napoleón III —a quien había conocido-, tuvo una conducta internacional poco prudente. Planeó dominar el Paraná y el Río de la Plata hasta la Banda Oriental del Uruguay enfrentándose sólo al Imperio del Brasil, pero pronto se encontró atrapado en un conflicto armado extremadamente crudo (llamado en Paraguay la Guerra Grande y conocido fuera del país como la Guerra del Paraguay o de la Triple Alianza, 18641870) al que se sumaron también, con la bendición británica, las tropas de los gobiernos de Buenos Aires y Montevideo. Después de una épica resistencia, el hombre que amaba tildarse de "Napoleón del Plata" fue asesinado por los brasileños en su último reducto, el rocoso anfiteatro natural de Cerro Corá; antes que él habían muerto entre doscientos mil y quinientos mil paraguayos quedando el país completamente asolado y reducido en su territorio.

\footnotetext{
${ }^{1}$ La narración, escrita por Roa Bastos hacia los trece años, fue publicada en Asunción en 1979 y de nuevo, el año siguiente, dentro de la colección de cuentos del autor, Antología personal (México: Ed. Nueva Imagen, 1980). Al respecto véase Ruffinelli.

${ }^{2}$ Véase, en el primer capítulo, lo que el viejo Macario Francia contaba del Supremo Dictador a Miguel Vera y a los demás niños del pueblo.
} 
Pues bien, como he adelantado arriba, el mariscal Francisco Solano López aparece tanto en la larga narración "El sonámbulo", como en la segunda versión modificada de Hijo de hombre publicada por Roa Bastos a comienzos de los años ochenta. Sin embargo, la atención del escritor para con Francisco Solano López no se ha agotado ya que en su reciente novela El fiscal Roa Bastos ha añadido otras piezas al mosaico del "Napoleón del Plata". Merece la pena detenerse sobre algunos caracteres y cualidades de semejante afición.

La publicación de "El sonámbulo" fue bastante trabajosa porque este largo cuento en primer término apareció en tres entregas en el diario de Asunción $A B C$ Color en 1975-76 con el título de "Cerro Corá (1870) I", "Cerro Corá(1870) II. El resplandor", y “Cerro Corá (1870) III. El final”. Ahí el título de "El sonámbulo" se reservaba sólo a la parte inicial del escrito, esto es, la "Nota prelimiar del compilador". Al contrario, el texto que se editó en diciembre de 1975 en la revista argentina Crisis ya tenía el título definitivo de "El sonámbulo". 3 Según parece, estos textos —o quizá sólo el que lleva el título general de "Cerro Corá" - se publicaron sin final, y la versión completa de "El sonámbulo" apareció por primera vez dentro de una de las lujosas obras del finísimo editor italiano Franco Maria Ricci. $^{4}$

Lo que no termina de sorprender, desde el comienzo de la lectura, son las analogías y semejanzas entre "El sonámbulo" y Yo el Supremo. El texto, que no ha recibido casi atención por parte de la crítica, parece ser una segunda aplicación, un poco reducida, de los muchos recursos empleados por el autor paraguayo en su recreación del Doctor Francia. Como ya en Yo el Supremo hay un compilador: es anónimo, pero el lector un poco avisado se da cuenta de que lo que aquél dice de sí (haber trabajado como periodista en Asunción en 1947 , etc.) lo envía sin rodeos al mismo Roa Bastos. Este compilador encuentra en el archivo de la Fiscalía General del país guaraní una memoria, no clasificada, que remonta a la primera década del siglo XX y que un antiguo veterano de la Guerra Grande, Silvestre Carmona, dirigió a José Segundo Decoud, fiscal general de la nación e importante personalidad de la época. El compilador publica el texto en la transcripción mecanografiada que sustituyó al original mal escrito a lápiz sobre papel de envolver, y que va acompañada en los márgenes de las observaciones redactadas, con buena letra y mejor pluma, ${ }^{5}$ por el mismo fiscal. Estas notas, que son en conjunto veintinueve, devuelven a la memoria del lector las más numerosas apostillas (son setenta y tres) que salpican Yo el Supremo a pie de página o que van integradas al discurso narrativo. Dichas intervenciones tienen - como ya en la novela mayor, y de manera aun más sistemática - la función de censurar la versión

\footnotetext{
${ }^{3}$ Véase Ferrer Agüero 314-320.

${ }^{4}$ Me refiero a la versión italiana del libro de Cándido López editada por Franco María Ricci. Ocho años más tarde el mismo editor promocionó también la edición en español: pues en ese texto, 25-104, se puede leer la versión definitiva de la narración de Roa Bastos. Que "Cerro Corá" y quizá "El sonámbulo" publicado en la Argentina en 1975 tienen un final trunco y un texto no exactamente igual al editado por Franco María Ricci se deduce leyendo los pocos pasajes reproducidos por Luis María Ferrer Agüero. No he tenido la posibilidad de cotejar directamente los textos publicados en $A B C$ Color y Crisis con el de Franco María Ricci, lo que tampoco ha hecho Ferrer Agüero.

${ }^{5}$ El volumen de Franco María Ricci presenta esos párrafos como si fueran escritos a mano. Lo mismo se había hecho con el pasquín anónimo con que empieza Yo el Supremo: véase, por ejemplo, la edición al cuidado de Milagros Ezquerro 93.
} 
presentada: el fiscal Decoud, pues, desarrolla el mismo papel de "corrector" confiado en Yo el Supremo y censura a los dobles del Dictador, a las voces fantasmas, a "la mano de hierro", etc. Además, de destinatario de la memoria de Carmona Decoud pasa a ser a su vez narrador ampliando la oferta de cambiantes puntos de vista. Otro pequeño rasgo común a las dos obras es la alabanza de la palabra oral versus la palabra escrita, ${ }^{6} \mathrm{y}$ podrían encontrarse ulteriores elementos parecidos.

Como en la gran novela inspirada por el Doctor Francia, también en "El sonámbulo" la gran mayoría de los personajes existieron realmente. La verosimilitud es mayor aquí, tanto que el largo cuento podría parecer a los que tienen algún conocimiento de la historia paraguaya, de inmediato, como una novelita de recreación histórica bastante "de confiar". El hecho es, en efecto, que Roa Bastos aparentemente manipula menos a las personalidades que escoge. No sufren alteraciones notables, por ejemplo, los catedráticos extranjeros Pierre Dupuy e Ildefonso Antonio Bermejo que llegaron al Paraguay contratados por Carlos Antonio López. ${ }^{7}$ Históricamente sin tacha es la aparición del padre Fidel Maíz ("El sonámbulo" 48, 50 y siguientes), cura paraguayo matusalémico (1828-1919), política y moralmente rocambolesco, que tuvo que escribir unas largas memorias para justificar su permanente condición de "chaquetero". ${ }^{8}$ El mismo mariscal López no sufre en el cuento, a pesar de las invenciones del autor, desbarajustes de mucha monta. ${ }^{9}$

El que sí padece cierta manipulación es José Segundo Decoud, pero hay que llevar a cabo una detenida pesquisa bio-bibliográfica para darse cuenta. En efecto, a las facciones históricamente conocidas de ese político (1848-1909) que se señaló como enemigo de Francisco Solano López tanto con las armas (luchó con las tropas de los Aliados durante la primera parte de la guerra) como en su sucesiva acción de gobierno, ${ }^{10}$ Roa Bastos añade que tuvo el cargo de fiscal general ${ }^{11}$ y también le atribuye "un voluminoso y furibundo libelo contra Francisco Solano López, titulado Un tirano del Paraguay" ("El sonámbulo" 29). El escritor paraguayo hace esto por su personal afición al oficio de fiscal - atracción sobre la que volveré - y porque el Decoud histórico, a pesar de ser un prolífico polígrafo, no resulta haber escrito cosas efectivamente encarnizadas contra el mariscal derrotado en Cerro

\footnotetext{
"Afirma de sí Carmona en "El sonámbulo": "Sin memoria y sin lengua, sólo puedo escribir; poner lo más mío, lo más oculto de mí, en lo que hay de más ajeno a uno: la palabra escrita. Lo bueno de lo escrito, sin embargo, es que uno lo deja de lado y desaparece. Con sólo desviar la atención de la mirada de lo escrito, eso se borra, se extingue" (Roa Bastos en López, Imágenes 31). El pasaje es identico en "Cerro Corá (1870) I". Las semejanzas con Yo el Supremo son subrayadas también por Ferrer Agüero (317).

${ }^{7}$ El francés Dupuy y el español Bermejo aparecen en las páginas 42,44 y 46 de "El sonámbulo". Véase Velázquez, 169, 170, 172 y 205.

${ }^{8}$ Véase Velázquez, 48, 50 y siguientes. El padre Maíz ha ejercido sobre Roa Bastos una fascinación casi igual a la del mariscal López, tanto que dicho sacerdote se encuentra con frecuencia también en las siguientes obras del escritor.

${ }^{9}$ Sobre el "Napoleón del Plata" hay por supuesto una larga bibliografía. Véase O'Leary.

${ }^{10}$ Véanse el libro de Calzada, la Enciclopedia Universal Ilustrada Europeo-Americana 1236 y Velázquez, 199-200.

" No ocupó ese cargo, pero sí fue por dos veces juez de la Corte Suprema, además de ministro de Justicia, de Relaciones Exteriores, etc. (Velázquez).
} 
Corá. ${ }^{12}$ Entonces - por si fuera necesario— se fortalece la posición de ese miembro de la oligarquía asunceña dándole algunos rasgos antilopiztas del aun más importante político e historiador paraguayo Cecilio Báez (1862-1941). Este último, que fue jefe del partito liberal, diplomático, ministro de Relaciones Exteriores y presidente provisional de la República en 1906, construyó gran parte de su fortuna pública oponiéndose decididamente a la tradición dictatorial del país que iba desde los jesuitas al "Napoleón del Plata" pasando por el Doctor Francia. Tanto que de Báez se escribió triunfalmente: "Publicista elocuente, inculcó en la conciencia del pueblo paraguayo ideas de libertad y propagó los principios de la democracia. En un libro que se ha hecho famoso, La tiranía en el Paraguay, condenó en estilo severo a los déspotas de su patria, especialmente al mariscal Francisco Solano López. Conmovió este libro tan profundamente el alma paraguaya, que las masas ciudadanas, avergonzadas de su triste pasado, se irguieron y armaron una revolución regeneradora. Báez es considerado con justicia como el primer líder liberal de las multitudes, que le han aclamado en diversas ocasiones (...)" (Enciclopedia Universal 1195). Perdóneseme la cita un poco larga, pero era necesaria: hay que empezar desde semejantes descabelladas alabanzas para comprender en cierta medida — valga anticiparlo ya desde ahora— la actitud bastante prolopizta de Roa Bastos, así como para entender la alta opinión que el escritor tiene del Doctor Francia es preciso remontarse a las patrañas escritas contra este último y a las posturas de "vendepatrias" frecuentemente adoptadas por los regidores del Estado paraguayo desde 1870.

Igualmente interesante es el caso del personaje Silvestre Carmona. Un oficial de tal nombre existió realmente, pero éste antes de "El sonámbulo" no era sino uno de los muchos muertos de la Guerra Grande. Roa Bastos le ha dado nueva vida y quizá dignidad aprovechando para su construcción muchos rasgos biográficos de otro más importante veterano, Juan Crisóstomo Centurión (1840-1902), quien fue alumno sucesivamente de la escuela de Matemáticas, de la Escuela Normal y del Aula de Filosofía de Asunción, estuvo en Europa, llegó a coronel durante el conflicto y fue herido en Cerro Corá (hasta aquí, exactamente como el Carmona reinventado) y después - en esto el escritor se aleja del modelo- ocupó altos cargos públicos. ${ }^{13}$

Sin embargo, de entre las fuentes que pudieron concurrir al dibujo del personaje Carmona hay que añadir -hecho que tampoco parece haber sido hasta ahora observado por la crítica - un relato del anglo-hispano-paraguayo Rafael Barrett cuya obra, es sabido, ha constituido por Roa Bastos una constante fuente de inspiración y de ejemplo moral. En efecto, en el pequeño boceto "El veterano"14 se encuentra la figura de un antiguo oficial de la Guerra Grande que va "lleno de vagas desconfianzas y remordimientos" por haber salvado su vida en la fase final de la lucha escapándose de la despiadada justicia de los tribunales de guerra paraguayos. El relato, que resulta más bien hostil al mariscal, permite también medir la distancia temporal e ideológica que hay, a pesar de las influencias recibidas, entre Roa Bastos y su mentor Barrett. ${ }^{15}$

\footnotetext{
${ }^{12}$ Publicó Recuerdos históricos. Homenaje a los Próceres de la independencia y otras obras, artículos y folletos de tema histórico y político.

${ }^{13}$ Sobre Centurión véase Velázquez, 173 y 203.

${ }^{14}$ Está incluido en la antología, prologada por Roa Bastos, de Rafael Barrett, 48-49.

${ }^{15}$ Puede destacar'se que al pie de la página 48 en la antología de Barrett, hay una nota biográfica sobre Francisco Solano López que contiene una referencia a la historiografía revisionista rioplatense.
} 
Precisamente Carmona cuenta la historia de su vida. Si su origen es emblemático nació el mismo día en que murió el Dictador Supremo-, también su niñez tiene rasgos originales. ${ }^{16}$ Su juventud queda marcada por los servicios cumplidos al lado del mariscal como su secretario en Europa (1853-54); luego, ascendido poco a poco de soldado raso a coronel en la Guerra Grande, Carmona sigue sufriendo el embeleso del trágico presidente. Salen así detenidos bocetos del mariscal y de su entorno, de sus amores con la bellísima irlandesa Elisa Alicia Lynch, de las conjuraciones de la familia, de las diferentes fases del conflicto, etc. Carmona, después de haber contado la muerte del mariscal en Cerro Corá y la mutilación que él mismo sufrió en esta última refriega, pone punto final a la narración con una sorprendente confesión revelando haber sido él quien reveló a los brasileños la manera de penetrar en el inexpugnable reducto paraguayo.

Como en parte ya he anticipado, hay que subrayar también la aparición en "El sonámbulo" de una serie de figuras y temas destinados a volver, más desarrollados, en sucesivas ficciones del autor: desde la interpretación de Francisco Solano López como "El Cristo paraguayo" elaborada por el padre Maíz - visión que es aquí revelada por una apostilla del fiscal Decoud ("El sonámbulo" 96)— ${ }^{17}$ hasta la riña entre las tropas imperiales del Brasil sobre quién remató realmente al mariscal paraguayo y sobre a quién, pues, tocaba el premio en libras esterlinas que se había prometido al ejecutor ("El sonámbulo" 102, 104), pasando por la evocación de un misterioso pintor enemigo que intentaba fijar en el lienzo las batallas ("El sonámbulo" 72, 74).

"El sonámbulo" tolera enfoques muy diferentes. El crítico puede juzgar que todo no es sino palabra paródica y que la intención del autor es sugerir significados opuestos a los que el texto aparenta. Pero, aquí y en general, ¿en qué se basa el comentarista para expresar semejante juicio? A veces, precisamente unos pasajes del texto empujan hacia dicha interpretación (ocurre tanto aquí como en Yo el Supremo y, lo veremos luego, en El fiscal); sin embargo, ¿son suficientes unos pasajes para tildar de "paródica" toda una obra, o es preciso considerar como tales únicamente esas partes? Precisamente en "El sonámbulo" semejantes indicios reveladores no abundan: trozos explícitos en el dicho sentido se encuentran casi sólo en la ya recordada querella relativa a la atribución del golpe mortal que acabó con el "Napoleón del Plata" ("El sonámbulo" 104) $)^{18}$ y en la evocación de otra igualmente trillada polémica entre los cronistas de la época, esto es, si al morir el mariscal dijo "Muero con mi patria" o "Muero por mi patria" ("El sonámbulo" 100), referencia que hay que poner en relación con el constante rechazo de la historia oficial que siempre ha manifestado Roa Bastos. ${ }^{19}$

\footnotetext{
${ }^{16}$ La relación de Silvestre con el padre (véase "El sonámbulo", 32-40) tiene algunas semejanzas con aquélla existente entre el joven Francia y su progenitor: particularmente, hay cierta analogía entre el viaje ahí contado y el recorrido fluvial presente en Yo el Supremo (1983, 436-438).

${ }^{17}$ Corolario de la misma interpretación "cristológica" es inventar que el mariscal sufrió una herida en el costado: también este elemento volverá a ser repetido sucesivamente por Roa Bastos ("El sonámbulo" 100 ).

${ }^{18}$ Lo dicho se revela sin rodeos a través del "corrector" Decoud, pues éste, sin aparente ironía, comenta positivamente el hecho de que el general brasileño Correia da Câmara recibió, por su hazaña, el título de vizconde de Pelotas.

${ }^{19}$ Hay otra referencia al tema ("El sonámbulo" 78), al discutir si en la batalla de Piquisirí (Roa Bastos, afincado en su desprecio por las grafias del guaraní más acreditadas, escribe Pykysyry) había o no piedras detrás de las cuales López podría haberse parapetado.
} 
Dudoso es el posible significado paródico de algún que otro pasaje, mientras que sería arbitrario pensar en focalizar de esa manera la mayor parte de "El sonámbulo". Entonces, no hay más remedio que recurrir al macrotexto del autor, esto es, a sus obras anteriores, sin excluir tampoco sus escritos no literarios (político-ideológicos, etc.) e incluyendo también, diría yo, las vivencias de Roa Bastos que parecen "indudables" y que no necesitan ser detectadas a través de dudosos análisis psicológicos. Volveré más detenidamente sobre el asunto en la conclusión de este artículo. Por ahora, para dar un ejemplo in corpore vili de este enfoque, dejemos de lado a Francisco Solano López y centrémonos en su padre. Es curioso que las pocas referencias a Carlos Antonio López en el texto sean aparentemente neutras. Sin embargo, bien mirado, y de adoptar la óptica arriba dicha, deben considerarse como negativas: en efecto, la muy rápida referencia al hecho de que bajo su gobierno se castigaba al alumno que hablase guaraní en la escuela ("El sonámbulo" 44) no puede interpretarse de otra manera si se conoce la defensa de la lengua vernácula que muy a menudo ha desarrollado Roa Bastos. ${ }^{20}$ Sin embargo, hay casos un poco más crípticos y uno de éstos son los desaforados elogios del Paraguay que salpican el texto. ${ }^{21}$ ¿Cómo enjuiciarlos? El crítico presumido y superficial los interpretaría como una tomadura de pelo de un trasnochado nacionalismo, pero la respuesta es exactamente la contraria si vamos a ver los escritos no literarios del autor, donde se encuentran afirmaciones parecidas pero dichas en serio. ${ }^{22}$

¿Por dónde van los tiros de Roa Bastos? Si hay un mensaje ético-político - y yo creo que sí-, parte de éste consiste en el rechazo, como ya en Yo el Supremo, de la verdad histórica oficial, lo que se subraya también de manera abierta en el comienzo del texto condenando a los que se contentan con estar sentados en una verdad a medias, la que se encuentra en "un sólo lado de la espada". ${ }^{23}$ En esta idea de la complejidad de la historia, sin embargo, "El sonámbulo" parece alejarse un poco de la novela anterior. Si ahí Roa Bastos había rehusado completamente las pautas de la novela histórica y las teorizaciones sociológicas de personajes emblemáticos a lo Lukács, en "El sonámbulo" en cierta medida vuelve a caminos más tradicionales confiando a Decoud y a Carmona la tarea de reproducir en el cuento de manera estructural la oposición entre lopiztas y antilopiztas que dividía y, en parte aún divide, la sociedad paraguaya (Ferrer Agüero 319).

Es difícil afirmar de manera tajante que Roa Bastos aboga por una cabal revaloración de Francisco Solano López, ${ }^{24}$ pero es cierto que toda la obra del escritor no se puede entender si uno no se remonta tanto al nacionalismo paraguayo tradicional y de vieja cuña, como al revisionismo histórico y a las actitudes anti-imperialistas que desde los años veinte muy a

\footnotetext{
${ }^{20}$ Esto a pesar de las polémicas producidas: véase Rodríguez Alcalá.

${ }^{21}$ Véase, por ejemplo, "El sonámbulo" 46.

${ }^{22}$ Podrían ofrecerse muchas citas, entre las cuales el elogio que trasuda vieja retórica nacionalista de la grandeza paraguaya que se encuentra en los tres artículos escritos por Roa Bastos después de la caída de Stroessner y publicados en El País de Madrid (18, 19 y 20 de mayo de 1989) con el título colectivo de "La situación en Paraguay".

${ }^{23}$ El juicio se encuentra dos veces en el cuento, repetido por el compilador y por Carmona ("El sonámbulo" 27,29$)$.

${ }^{24}$ En quizá la más seria de sus apostillas el fiscal Decoud subraya las diferencias entre el verdadero Napoleón (el primer Bonaparte) y el "Napoleón del Plata" ("El sonámbulo” 70).
} 
menudo comparten las derechas radicales y las izquierdas revolucionarias. El mensaje ideológico no es claro porque Roa Bastos tiene sus contradicciones y sabe que las tiene: por eso, tal vez, de pasada pinta a Carmona como dudoso a veces y dividido en su interior entre la fidelidad patriótica y las ideas liberales recibidas durante su estadía en Inglaterra.

Hay otras cosas que empujan a considerar "El sonámbulo" un texto a su manera comprometido: una de las pruebas es que Carmona afirma que su conflicto interior se modificó al detectar a paraguayos y a enemigos como una cosa sola, al darse cuenta de la solidaridad entre los unos y los otros que la guerra y la muerte producían ("El sonámbulo" 72). El pasaje es muy interesante porque significa una vuelta ético-temática a lo ya contado, a propósito de los estragos en el Chaco entre paraguayos y bolivianos y de la identificación entre el que mata y el que es matado, en uno de los mejores cuentos de El trueno entre las hojas (1953)..$^{25}$

No faltan referencias crípticas a la contemporaneidad. Cuando al comienzo del cuento el compilador recuerda su investigación periodística sobre unos contratos mercantiles en las comarcas fronterizas del país, alude tanto a las ventas al por mayor, con depreciación, de las tierras catastrales después de la derrota de 1870 , como a las alienaciones masivas de tierras paraguayas en favor de adquisidores brasileños en los años de Stroessner. Los pasajes tienen un claro carácter de reivindicación nacional, especialmente si los relacionamos con un episodio acaecido muy poco despúes de la probable redacción de las páginas de "El sonámbulo" - - cl cual aclara el momento histórico-político y la reacción patriótica del escritor- esto es, que en el marzo de 1976 en la Cámara de diputados federal del Brasil se pidió la anexión del Paraguay. ${ }^{26}$

En fin, para concluir, un rápida valoración estética, nota que a menudo falta en los estudios. El texto es muy valioso: quizá uno de los mejores del autor. Sus cualidades destacan mejor por ser "El sonámbulo" bastante corto, lo que en cierta medida viene a dar nueva vida, confirmándolo, a lo que se dijo de Roa Bastos antes de la aparición de Yo el Supremo, esto es, que su medida narrativa era la del cuento. Mientras la historia se desarrolla de manera tradicional, la narración tiene su punto de fuerza en la alternancia entre el tono sosegado, casi clásico, de la parte precisamente narrativa, y el cariz al contrario más variado de los diálogos. De cualquier modo, "El sonámbulo" resulta muy homogéneo y apenas puede señalarse algún desliz del autor. Hay, sin embargo por lo menos un infortunio y es la imagen de la uña del secretario creciendo sin parar ("El sonámbulo" 88): si bien insertado de manera rápida, esto molesta por contrastar completamente con el matiz realista de la narración y por no caber dentro del contexto, tanto que el pasaje parece ser una sobra de las muchas invenciones incluidas en Yo el Supremo, a la cual Roa Bastos desafortunadamente no supo renunciar. A pesar de que las fuentes de "El sonámbulo" son, desde luego, como ya ocurrió en Yo el Supremo, las memorias y documentos de la época -las Proclamas y cartas del Mariscal Francisco Solano López que fueron recogidas en 1957, las Etapas de

\footnotetext{
25 "Era despreciable la circunstancia de que uno fuese el exterminador y otro la víctima inminente". "Recordó nítidamente al soldado enemigo a quien había abatido con su ametralladora mientras se retorcía en una pesadilla. Soñó que aquel soldado enemigo lo abatía ahora a él mismo, que se hubiera dicho que era su hermano mellizo" (Roa Bastos, El trueno 74, 76).

${ }^{26}$ El episodio es recordado por Marini Palmieri 342.
} 
mi vida del Padre Maíz, las Memorias de Juan Crisóstomo Centurión, etc.-, el recurso directo a los textos ajenos es débil y sin comparación alguna con lo realizado en la novela inspirada por el Doctor Francia: probablemente, también éste es otro elemento que contribuye a dar a "El sonámbulo" su envidiable calidad.

Pasemos a Hijo de hombre. Es sabido que de esta primera novela suya, aparecida en 1960, Roa Bastos dio una nueva versión unos veinte años después. Lo que nos interesa se encuentra en el capítulo VII, titulado "Destinados".

Ya en la redacción original hay referencias al mariscal caído en Cerro Corá, a través de la evocación del libro de memorias de Fidel Maíz: en la ficción este volumen es recibido por uno de los presos en el penal militar en que está también Miguel Vera, el personaje que es el enlace entre los diferentes episodios de la novela y también el narrador en los capítulos impares. También Vera termina por leer las dichas memorias: no hay mucho que subrayar sino que, además de recordar la tesis del padre Maíz que tildaba Francisco Solano López de "Cristo del pueblo paraguayo", al compañero dueño del volumen se le define "antilopizta" (Hijo de hombre 1971, 172-173).

Referencias más largas al tema se encuentran en la segunda versión publicada del mismo capítulo (Hijo de hombre 1992, 245-252, 263). Lo escrito antes se mantiene y se le añaden cosas. La atención se concentra más sobre el padre Maíz que sobre el mariscal: sin embargo los dos están muy unidos el uno con el otro y ambos reciben un enfoque muy controvertido. La figura del cura chaquetero le fascina a Miguel Vera, quien en sus meditaciones lo define como el "anti-héroe por excelencia" del Paraguay; Francisco Solano López, por su parte, a pesar de haber llevado "al suicidio colectivo a su pueblo, muere como un héroe". También la evocación de la dúplice versión de la última presuntiva frase del mariscal agonizante parece poseer un significado diferente del que — sólo paródico, probablemente - tenía en "El sonámbulo", porque aquí la interpretación que Vera da a la querella reenvía sin duda alguna a una postura nacionalista. ${ }^{27}$

Hay indicios de que las páginas relativas a la Guerra del Paraguay insertadas en la segunda versión de la novela fueron escritas después de "El sonámbulo" y en los años en que Roa Bastos meditaba la novela luego publicada en 1993, El fiscal. ${ }^{28}$ Es cierto, de cualquier modo, que su enfoque de la historia paraguaya ya no es el mismo de 1960. Sería demasiado simplista o naïf suponer que hubo tales insertos sobre Francisco Solano López y Fidel Maíz en la nueva redacción sólo para cubrir mejor un vació cronológico-temático. Responden, al contrario, a un profundo cambio tanto ético-político como estético del autor, que lo lleva a franquear Hijo de hombre en su conjunto de todo significado unívoco

27 “(...) surgió la interminable polémica sobre si el Mariscal lanceado por el cabo brasileño Chico Diavo había exclamado ;Muero con ... o muero por mi patria! Habría que zanjar en todo caso en que el sentido de la frase no residía en la preposición, sino en el hecho más respetable de que el jefe de una nación murió asesinado por los invasores por y con la patria. Irrisión de las frases póstumas" (Hijo de hombre 1992, 246).

${ }^{28} \mathrm{Si}$ fuera necesario, el siguiente párrafo alude a la redacción de El fiscal: "Alguien debería escribir alguna vez la historia de gente como Maíz porque llegará un día en que patibularios fiscales se arrogarán el derecho de juzgar y condenar a este pueblo (...)" (Hijo de hombre 1992, 252). 
quitándole el maniqueísmo moral de la primera versión ${ }^{29} \mathrm{y}$, en el caso específico del mariscal, a alejarse de un enfoque rápido y casi neutro de la tragedia de Cerro Corá. La decidida opción de Roa Bastos en favor de la polisemia, expresada en los cuentos de la segunda época y en Yo el Supremo, opera también aquí dando al presidente López y al padre Maíz, como ya dicho, una fortísima ambigüedad a pesar de las limitadas páginas añadidas.

Por lo que se refiere a El fiscal, obra con la que se concluye la "Trilogía paraguaya" de novelas dedicadas por Roa Bastos a su patria, ${ }^{30}$ hay que decir de antemano que es de muy poco valor. Antes que nada, por la altura del propósito - encarar la cuestión de obtener la perfecta justicia - y lo veleidoso de la pretendida demostración. Esta se realizaría - lo afirma el autor, pero al lector se le escapa totalmente- a través de la historia de Félix Moral, un profesor paraguayo exiliado en Francia que, empujado por su odio hacia el presidente Stroessner y también por algunos enigmáticos acontecimientos, vuelve a Asunción para matar al dictador: descubierto, Moral es torturado y luego asesinado sin que su amada compañera consiga salvarlo. El fiscal, con el cual Roa Bastos vuelve a pautas de narración más bien tradicionales, ${ }^{31}$ se revela muy flojo también por la calidad externa de gran parte de las reflexiones ético-políticas (fijense en lo explícito del apellido del protagonista) y por los frecuentes tratos folletinescos del texto..$^{32}$ Una novela fatigosa, que especialmente en su segunda parte se puebla de personajes tullidos y se desarrolla en un clima agobiante. ${ }^{33}$

Otro discutible apartado es el de la larga redacción de la obra. Hace falta recordar al respecto que ya en 1976 el escritor había anunciado estar trabajando sobre El fiscal, tanto que cuando apareció "El sonámbulo" muchos pensaron que el relato no era sino una anticipación de la dicha obra in fieri. Pasaron sin embargo muchos años antes de que Roa Bastos volviese a hablar detenidamente de aquella novela suya: al hacerlo, dijo haberla quemado por su insuficiente calidad y por ser semejante texto inoportuno después de la

\footnotetext{
${ }^{29}$ Para una interpretación de los cambios introducidos en la novela que hace más bien hincapié sobre la "poética de las variaciones" y la persistente reflexión de Roa Bastos sobre la impotencia de la escritura y su contradictoria relación con la realidad, véase Moreno.

${ }^{30}$ Que las tres obras "componen la trilogía sobre el 'monoteísmo' del poder, uno de los ejes temáticos de mi obra narrativa", ha sido afirmado por Roa Bastos en el prólogo a El fiscal (9).

${ }^{31}$ En casi toda la novela se emplea la narración en primera persona, porque es una ideal carta póstuma escrita por el protagonista; sólo el epílogo se debe a la mujer amada por Moral. En una de las muchas entrevistas - "Quemo mis malas novelas", en La verdad (Murcia), 22 de febrero de 1994, 47- el escritor ha afirmado necesitar ahora "crear con una escritura más llana y simple".

${ }_{32}$ Véanse las descripciones del perfecto amor entre el protagonista y su amada Gimena/Morena o de la atracción casi fatal que Moral sufre por una misteriosa alumna suya: en el relato de una más o menos onírica cópula con esta última la novela toca el fondo de la cursilería (El fiscal 118 y siguientes).

${ }^{33}$ Quizá eso revela la influencia de otra novela dedicada al retorno de un exiliado, esto es, $L a$ desesperanza de José Donoso. Exceptuando alguna que otra valiosa crítica (por ejemplo, la de Rodríguez Alcalá sobre "La excavación"), un detallado examen de las posibles influencias de otros escritores hispanoamericanos sobre Roa Bastos queda todavía por hacer. Por lo que se refiere a $E l$ fiscal, además de lo dicho podría uno a lo mejor llegar a formular también conjeturas de menor monta y suponer que en el origen del personaje de Clovis de Larzac (que empieza a aparecer en la novela desde la página 136) está tal vez el nombre del autor del más descabellado libro nunca escrito sobre las reducciones jesuíticas, esto es, el francés Clovis Lugon, así como en la recreación del aristocrático ambiente familiar del mismo está quizá la novela Una familia lejana de Carlos Fuentes.
} 
caída del presidente Stroessner el 3 de febrero de 1989. ${ }^{34}$ Cuando finalmente El fiscal apareció de verdad, a finales de 1993, su autor afirmó que el texto lo había escrito en sólo cuatro meses y que era completamente diferente del anterior. ${ }^{35}$ En realidad, lo que ha revelado Roa Bastos sobre la precedente escritura de la novela permite afirmar que los cambios introducidos en la última redacción son bastante limitados y sobre todo que la perspectiva ético-política no parece haberse de veras alterado. ${ }^{36}$ De cualquier modo, algunas partes de la novela presentan acusadas relaciones temáticas con cuanto ya habían sido escritas anteriormente por su autor y precisamente dichas páginas, en la cuales se trata de manera bastante amplia de Francisco Solano López, son las más interesantes del volumen, las que quizá salvan el texto de un total fracaso.

En la primera de las tres "secciones" de El fiscal que especialmente nos interesan la trágica muerte del "Napoleón del Plata" vuelve a ser evocada a través de una sorprendente recreación ficcional. Félix Moral recuerda lo ocurrido cuando fue involucrado en el rodaje de una película sobre la Guerra del Paraguay. El guión escrito por él, bastante fiel a los hechos, fue rechazado por la compañía cinematográfica y substituido con otro redactado por un norteamericano: se empezó entonces a rodar esa nueva versión fílmica cargada de terror, sexo y violencia - es suficiente decir que al centro del drama se pone un inventado amor lesbiano entre la Lynch y otra antigua amante del mariscal, Pancha Garmendia- hasta que Stroessner, habiéndose dado cuenta de que la película representaba una grotesca mofa de "la epopeya sagrada para los paraguayos"( El fiscal 45), pone término al rodaje bombardeando a actores y técnicos.

Hay que reconocer que la invención de Roa Bastos en dicho episodio es genial. Le permite, además, profundizar lo contado en pasado sobre la muerte de Francisco Solano López. En "El sonámbulo" se había subrayado, con detalles sombríos no se sabe en qué medida exactos, el escarnio sufrido por su cadáver. ${ }^{37}$ En El fiscal el escritor se supera transformando el simple vituperio en una crucifixión del cuerpo emasculado. Este crescendo tremendista, históricamente arbitrario, y que evoca lo ocurrido al jefe político

\footnotetext{
${ }^{34}$ Sobre el tema salieron en la prensa muchos artículos. Véanse, por ejemplo, los tres escritos de Roa Bastos cuyo título general es "La quema de una novela" aparecidos en El País (Madrid, 26, 27 y 28 de junio de 1989) respectivamente, 42, 44 y 40, o la entrevista de Andrés F. Rubio, "Roa Bastos, la literatura como ascesis", siempre en El País (19 noviembre 1989) 30. Además, en el muy rápido prólogo a El fiscal (9) se encuentra: “(...) la primera versión de esta obra fue escrita en los últimos años de una de las tiranías más largas y feroces de América Latina. En 1989 una insurrección abatió al tirano. La novela quedó fuera de lugar y tuvo que ser destruida. El fruto estaba inmaduro" (9). ${ }^{35}$ En el prólogo arriba citado el escritor afirma que "una versión totalmente diferente" surgió de abril a julio (no da el año, pero parece ser 1993). Roa Bastos ha vuelto a hacer hincapié en lo rápido de la re-escritura en ocasión de la presentación de la novela en Madrid, el 2 de noviembre de 1993.

${ }^{36}$ El punto de vista de Moral es relativo a la época de la dictadura porque él, y no podía menos, actúa cuando Stroessner está todavía en el poder. Pues, no hay novedad ideológica alguna hasta el rechazo, al final (El fiscal 352), de la necesidad de matar al dictador.

${ }^{37}$ El cuerpo desnudo del mariscal es ahí pisoteado por las tropas negras brasileñas. Además que en dicho pasaje ("El sonámbulo" 102), cierto desprecio para con los brasileños (a los que llama "macacos") motivado especial o aparentemente por las características raciales de una parte de ellos se encuentra tanto en "El sonámbulo" como en Yo el Supremo y en El fiscal.
} 
Melitón Isasi en Hijo de hombre, ${ }^{38}$ se relaciona con la obsesión cristológica también estrenada en la misma novela ${ }^{39}$ y permite recuperar de manera cabal la interpretación del mariscal como "Cristo paraguayo". ${ }^{40}$

Casi en la conclusión de la novela la Guerra Grande vuelve a evocarse. En esta sección domina, como ya en Yo el Supremo, un complejo juego intertextual. De entre los escritos a los que se acude sobresale la manipulación del libro de testimonio de Richard Francis Burton, el famoso orientalista británico traductor de las Mily una noches, que se encontraba entonces con encargos diplomáticos de confianza entre el Brasil y el Paraguay. ${ }^{41}$ Más interesante es observar - prueba que de sobra confirma la continuidad temática de Roa Bastos también en nimios detalles- la presencia ahí de elementos ya presentes en "El sonámbulo": como el dolor de muelas del mariscal, los tribunales de sangre o los tesoros sepultados acá y allá por el ejército paraguayo al huir, ${ }^{42}$ que estaban apenas dibujados en el precedente cuento pero que ahora aparecen con insistencia, o como las figuras del padre Maíz, de la Lynch y de Silvestre Carmona.

Sin embargo, lo que se desarrolla hasta más no poder son las referencias al pintor que en "El sonámbulo" aparecía sólo en dos páginas y se dejaba sin nombrar. Se trata del argentino Cándido López (sin ningún parentesco con el mariscal tocayo suyo), que participó con el ejército de Buenos Aires en la campaña del Paraguay hasta la batalla de Curupaytí (septiembre de 1866), en la que quedó mutilado de la mano derecha. Muchos años más tarde, habiendo aprendido a pintar con la izquierda, realizó unos cincuenta cuadros de la guerra aprovechando los bocetos a lápiz realizados en la época. Roa Bastos recrea a ese pintor, lo transforma hasta desdoblarlo y atribuirle lienzos que obviamente nunca han existido, como el de la crucifixión del mariscal; además, le hace sufrir una serie de mutilaciones crecientes - perdidas las manos, pinta con los pies; perdidos los pies, pinta con el pincel entre dientes, etc. - en otro crescendo tremendista que recuerda al lector la sangrienta serie de heridas y muertos de "Misión", el octavo capítulo de Hijo de hombre dedicado al conflicto del Chaco. Cándido López no es sino un instrumento para una complicadísima operación del autor —ésta sí acentuadamente paródica - dirigida a producir algunos efectos particulares en el enredo de la novela y a poner en duda - como ya lo hizo en Yo el Supremo en relación al Doctor Francia- el carácter fidedigno de todo testimonio sobre la guerra, fuese escrito o pintado. ${ }^{43} \mathrm{La}$ broma resulta más venenosa porque

\footnotetext{
${ }^{38}$ La crucifixión de Melitón Isasi se encuentra en el capítulo "Ex-combatientes" de la novela, tanto en la primera versión de la misma (263-264) como en la segunda (389-390). Aparece también en el cuento "Kurupí", insertado luego, con el título de "Madera quemada", en la segunda versión de Hijo de hombre (376).

${ }^{39}$ La historia del Cristo de madera tallado por el leproso Gaspar Mora marca la pauta en el primer capítulo de Hijo de hombre, de igual título.

${ }^{40}$ También aquí el mariscal presenta dos heridas: una en el vientre (la histórica) y una en el costado (la fingida, que sirve para ensalzar la comparación con Cristo) (El fiscal 30 y 32).

${ }^{41}$ Letters from the Battle-field of Paraguay (London: Tuisley Brothers, 1870).

${ }^{42}$ Es curioso observar que también un autor popular y lejano como el italiano Emilio Salgari conocía el mito y lo aprovechó, a comienzos del siglo, en su novelita denominada precisamente Il tesoro del presidente del Paraguay.

${ }^{43}$ Lo dicho tiene su pars seria en esta afirmación no paródica: "A lo largo de más de un siglo, la historia de la Guerra Grande (llamada de la Triple Alianza), continúa siendo materia de controversias y duelos
} 
el pintor argentino tenía una concepción histórico-estética completamente opuesta a la del escritor paraguayo. ${ }^{44}$

Si el intento irónico de Roa Bastos a propósito de Cándido López llega hasta la autocitación —detalle no infrecuente en el escritor-,${ }^{45}$ termina por abarcar también a Francisco Solano López en el final de la novela. La ironía no es muy sutil, pero es clara. En la ficción narrativa el mariscal, ya en sus postrimerías, ordena que el mes de febrero de 1870 , a pesar de no ser este año bisiesto, tenga 29 días: por eso su muerte histórica, ocurrida el $1^{\circ}$ de marzo, en la novela ocurre el día 29 de febrero, esto es, en un día inexistente, igual que la crucifixión del cadáver ... (288-289). ${ }^{46}$

Entonces, como tal vez quiere revelar el narrador ¿la novela es sólo un fingimiento y un divertissement? El que escribe estas notas cree que, a pesar de los frecuentes esperpentos e ironías, no toda la dicha recreación del desastre de Cerro Corá puede interpretarse como una tomadura de pelo. Como ya en "El sonámbulo" y en las páginas examinadas de Hijo de hombre, hay elementos que alejan de una interpretación paródica o festiva del texto en su conjunto. Destaca particularmente la descripción del cuerpo crucificado del mariscal cuyo explícito modelo es la pintura de Mathis Grünewald conservada en el museo de Unterlinden en Colmar: ella es tan intensa y vivida que no permite dudas. Las sensaciones que sufre el opositor del régimen contrastan con su creencia racional: si ésta le permite ver en el imaginario cadáver sólo un "hombre que no supo redimir ni salvar a su pueblo. Un Redentor asesinado", sin embargo Moral debe afirmar que "sentí en todo mi ser, sin poder evitarlo, el tremendo poder de los mitos de una raza, amasados con la sangre y el sacrificio de un pueblo mártir" y que "Todos mis prejuicios y viejos anatemas contra Lópezy la Lynch, contra el patrioterismo cimarrón de escarapela y machete, se borraron como bajo un sopolo demasiado fuerte. Sólo quedaron en mí el horror y el furor. Arrojé la pluma contra la pared y me lancé con los últimos soldados a defender a ese Titán ya muerto, suprema encarnación de la raza" (Hijo de hombre 32,30 y 34 respectivamente) ${ }^{47}$

Tiene uno la impresión de que el lector común queda completamente perplejo frente a estos acusados cambios de perspectiva. Esta reacción de ambigüedad la ensalzan aun las

interminables. A pesar de haberse escrito sobre ella bibliotecas enteras, sigue siendo totalmente desconocida. La historia oficial de los vencedores no ha hecho sino oscurecerla aún más y tornarla inverosímil como una tragedia que no ocurrió ni pudo haber ocurrido". (El fiscal 264).

${ }^{44}$ Del estudio de Marta Dujovne que precede el volumen Cándido López, Imágenes de la guerra del Paraguay 20-21, sabemos que el pintor creía que aun la simple modificación del matiz de un color de paisaje falsificaría la historia y que por eso supeditaba la armonía artística a la verdad histórica. ${ }^{45}$ Aludiendo al volumen publicado por Franco María Ricci, un personaje de la novela afirma que el "libro, de un gran valor artístico y polémico, está prologado por un escritor compatriota nuestro". Antes de esta cita (El fiscal 321) la novela contiene por lo menos otras tres referencias de Roa Bastos a sí mismo: véase $78,170,315$.

${ }^{46}$ Hay que recordar que en "El sonámbulo", al contrario, la muerte del presidente se fijaba en el 1 " de marzo, conforme a la fecha tradicional.

${ }^{47}$ De las otras muchas interesantes reflexiones, sólo añado la siguiente: “ (...) esa derrota final e infamante era la afirmación de un heroísmo singular; era, sin tapujos, una victoria moral (si puede hablarse de moral en la barbarie de las guerras, cualesquiera sean sus causas y objetivos por sagrados que se proclamen). Solano López obtuvo con su muerte y el exterminio de su pueblo un triunfo incalculablemente mayor que el de los vencedores (...)" (31). 
semejanzas existenciales entre el protagonista de la ficción y su autor real, ${ }^{48}$ las autorreferencias ya dichas, etc. Como el aspecto autobiográfico es muy pujante, parece insertado adrede, para que el lector procure identificar narrador ficticio y Roa Bastos, con un propósito embaucador que no excluye, sin embargo, cierto alarde de autorrevelación.

Cabe preguntarnos ahora las razones por las cuales el escritor paraguayo ha sufrido semejante atracción por Francisco Solano López. Sin duda hay que insertarla dentro de un amplio contexto, porque más de un dictador paraguayo ha fascinado a Roa Bastos. Pero, dentro del panorama del poder absoluto del país guaraní él aparentemente sólo ha escogido a tres, esto es, a José Gaspar Rodríguez de Francia, a Francisco Solano López y a Alfredo Stroessner. En realidad, los tres se reducen a dos, porque el último presidente-dictador del Paraguay, en el poder de 1954 a 1989, nunca ha sido enfocado por Roa Bastos de manera problemática: tampoco sirve para eso El fiscal, novela en la cual, al contrario, podría haber cabido un detenido enfoque de Stroessner. Éste, en efecto, es retratado como un adefesio o un títere esperpéntico, y la meditación que se le debía dedicar a él se traslada al mariscal presidente de hace un siglo.

No deja de causar intriga las concretas elecciones de personajes históricos del escritor paraguayo, junto a los rechazos que él hace de otras figuras - tanto individuales como colectivas- de la historia del país. Por ejemplo, si preguntáramos a un transeúnte cualquiera medianamente culto lo que le evoca de inmediato la palabra "Paraguay", probablemente que nos contestaría "las reducciones jesuíticas". Fíjense, al revés, en la casi completa ausencia de referencias importantes al mundo tropical de la Compañía de Jesús en la producción de Roa Bastos: alguna que otra notica, muy rápida, a confirmación del odio que le tiene el escritor a la obra de los padres, hasta dedicar en Yo el Supremo mucho más espacio, y simpatía, a los encarnizados enemigos internos de aquéllos en el siglo XVIII, esto es, a los Comuneros de Asunción (Yo el supremo 1983, 127 y siguentes). Otras ausencias podrían detectarse, entre las cuales hay que insertar la de Carlos Antonio López, el padre del futuro trágico mariscal, porque demasiado rápidas son las referencias, en "El sonámbulo", a ese autoritario presidente del país.

¿Cómo explicar, pues, esa particular selectividad histórica? A pesar de las maniqueas teorías que pretenden expulsar del análisis literario toda reflexión extratextual, no hay más remedio - como ya he adelantado - que acudir a los escritos políticos del autor paraguayo $\mathrm{y}$ a algunas declaraciones suyas, y sacar de las mismas y del conjunto de sus obras, oportunas conclusiones. Ya tratando de Yo el Supremo hubo quien, de manera muy acertada, subrayó cómo la ambigüedad del enfoque allí del Dictador influenciaba necesariamente el juicio del lector sobre una figura histórica y que, de limitar el análisis del Supremo sólo al nivel textual, las interpretaciones seguirían siendo contradictorias: así, pues, es difícil leer la obra sin examinar su contexto. ${ }^{49}$ Para reducir la ambigüedad y salir por lo menos parcialmente del

\footnotetext{
${ }^{48}$ Ambos son exilados paraguayos y profesores de literatura en una Universidad francesa; la mujer de Moral, Gimena/Morena, tiene los rasgos familiares y culturales de la actual esposa de Roa Bastos, Iris Giménez, etc.

49 Véanse las intervenciones de Paul Verdevoye en la "Discussion" seguida a la intervención de Jacques Leenhardt y en aquélla provocada por Rubén Bareiro-Saguier, "Niveaux sémantiques de la notion de personnage dans les romans de A. Roa Bastos", ambas en el coloquio del Centre Culturel International de Cerisy-La-Salle, publicado dentro del volumen colectivo al cuidado de Jacques Leenhardt, 74 y 185.
} 
atolladero del posible significado político de la más polisémica novela de Roa Bastos, creo que hay que hacer hincapié en la ideología y la actitud política práctica del escritor. ${ }^{50} \mathrm{Como}$ semejante análisis casi nunca se ha llevado a cabo, Roa Bastos ha terminado por sufrir un enfoque políticamente poco caracterizado y ser considerado como un hombre que, por lo menos, no destacaba dentro del casi generalizado compromiso con las izquierdas de los más celebrados escritores latinoamericanos. Pero es todo lo contrario. Los cuentos de El trueno entre las hojas, con una sola excepción, ${ }^{51}$ aparecen política o socialmente muy comprometidos, e igual juicio merece la novela Hijo de hombre. Aún cuando, a partir de los años sesenta, Roa Bastos cambió y profundizó mucho su técnica - acierta Giuseppe Bellini subrayando lo decisivo que fue en aquel entonces la frecuentación de la Editorial Losada, donde Roa Bastos pudo conocer a los escritores más importantes o recientes y ponerse literariamente al día-, el manejo plural de los puntos de vista y de los tiempos narrativos, la polisemia, la intertextualidad y todos los demás recursos de estilo que se aprecian en los cuentos de la segunda época (y luego, máxime, en Yo el Supremo) no van en menoscabo del empeño de militancia. Este último, igual que el estilo — claro está-, también se afina en los escritos de creación: así que, rechazada la denuncia directa, Roa Bastos persigue con mayor finura y más rodeos los objetivos de antes, esto es, una re-escritura revolucionaria de la historia y de la realidad político-cultural paraguaya.

Aclarar con precisión el exacto significado de esta tarea ideal es, sin embargo, difícil. El mismo Roa Bastos, cuando lo ha intentado a propósito de Yo el Supremo se ha enredado o se ha quedado corto. ${ }^{52}$ Lo que es cierto es que en los años setenta Roa Bastos subrayaba con mucho ahínco el carácter ideológico de toda obra literaria y hacía alarde de marxismo en todas sus variantes, ${ }^{53}$ y que todavía a mitad de los años ochenta, no obstante su trato frecuente con los ambientes mucho más moderados del PSOE en el poder en Madrid, y con los socialdemócratas de la Alemania Federal, su lenguaje político seguía repitiendo una serie de definiciones simplistas y de frases hechas de la retórica de izquierdas. ${ }^{54}$

${ }^{50}$ Véase Albònico 111-151.

${ }_{52}^{52}$ Sólo el relato "La gran solución" tiene acentos muy ligeros e irónicos.

${ }^{53}$ Los escritos más significativos de Roa Bastos son "Algunos núcleos generadores de un texto narrativo", en Escritura (Caracas, 4 de julio-diciembre de 1977) 167-193, y "Reflexión auto-critique a propos de Moi. Le Suprême, du point de vue socio-linguistique et idéologique. Condition du narrateur", leído en el coloquio del Centre Culturel International de Cerisy-La-Salle, y publicado dentro del volumen Littérature latino-américaine d'aujourd'hui 136-150.

${ }^{53}$ En los dos escritos citados en la nota anterior se pueden encontrar, reiterados con frecuencia, términos como "plusvalía", "explotación", "conciencia de clase", "falsa conciencia pequeñoburguesa", etc. Para un detenido análisis al respecto me permito enviar a la ya recordada ponencia "Un rompecabezas político y literario paraguayo: el Doctor Francia".

${ }^{54}$ Se puede escoger entre los muchos escritos militantes de Roa Bastos. Por ejemplo, "Hacia el pluralismo democrático en Paraguay", donde se encuentran afirmaciones como "carrera armamentista (...) incontrolables e incontrastables fuerzas del Pentágono(...) industria de guerra del imperio (...) democracia "pluralista" norteamericana (léase CIA, Pentágono, Departamento de Estado, agencias multinacionales de noticias)" (7-8) o "el sector agresivo y reaccionario de los militares uruguayos, servidores de estas oligarquías (...) regímenes adictos de neta inspiración nazifascista (...)" (6). 
Como todo lenguaje refleja una mentalidad y un método de análisis de la realidad, Roa Bastos en el campo político-ideológico parece pintar con brocha gorda y estar aparentemente bastante lejos - por sensibilidad, precaución intelectual, ganas de profundizar las causas de las cosas y los probables efectos de los remedios-de los elementos intelectuales y morales que caracterizan, o deberían caracterizar, la mentalidad liberaldemocrática.

Ya intentando comprender el muy ambigüo enfoque del Dictador desarrollado en $Y o$ el Supremo planteé en un trabajo anterior una serie de posibles explicaciones. ${ }^{55}$ Una podría ser que el hombre y el autor en Roa Bastos presentan aporías bastante parecidas: el escritor paraguayo no tiene ideas coherentes - o no revela completamente su ser-en la vertiente político-ideológica de la vida práctica, y en la ficción traduce estas dobleces. Por el contrario, de hacer hincapié sólo en la tosquedad de la concepción política de Roa Bastos, se podría también pensar que, como es allí esquemático por antiguas constricciones mentales, precisamente haciendo literatura se libra de semejantes lazos ideológicos y crea problemas y más problemas. No anda uno descaminado al subrayar la gran influencia que también las teorías deconstructivas de Jacques Derrida y otros estudiosos tuvieron sobre el escritor paraguayo desde los años setenta.

Roa Bastos enseña una no resuelta fascinación/adversión hacia la figura del "padre político", y ésta puede aplicarse no sólo al Doctor Francia sino también a Francisco Solano López. Véase especialmente el relato de "El sonámbulo". Ahí no se entienden bien las motivaciones de la traición final del coronel: sería ridículo, en efecto, abogar por un amor secreto de Carmona hacia la Lynch, como el texto parecería sugerir. Entonces, la explicación más prometedora es, otra vez, la del asesinato del progenitor. Por esta senda nos conduce, además de lo ya dicho, ${ }^{56}$ otro pasaje, esto es, cuando al ver por primera vez a Carmona Francisco Solano López lo llama por su nombre y el joven tiene la impresión de escuchar la voz de su padre difunto ("El sonámbulo" 36).

Como las dudas de Carmona entre la fidelidad patriótica y el rechazo de las necedades sangrientas parecen ser también las suyas, igualmente la traición y "el homicidio del padre" del coronel paraguayo son compartidas por Roa Bastos: como Carmona ha traicionado fisícamente a López, el escritor también lo ha traicionado con la pluma no teniendo el valor de defenderlo hasta la muerte y sin vacilaciones. Lo escrito luego en El fiscal -al contemplar al mariscal crucificado Félix Moral deja de lado todas sus creencias liberalrevolucionarias y se pone, por nacionalismo, al lado del héroe de Cerro Corá- podría tal vez interpretarse como una rectificación precisamente de lo dicho en "El sonámbulo". Lo confirmaría el acusado biografismo de El fiscal y también de la nueva novela publicada por Roa Bastos en 1995. No hay que olvidar, además, que Roa Bastos dijo a menudo tener una relación bastante frustrada con su vida y que echaba de menos una existencia activa, ${ }^{57}$ y

\footnotetext{
${ }^{55}$ Véase la ya citada ponencia "Una rompecabezas político y literario paraguayo: el Doctor Francia".

${ }^{56}$ Véase la nota 16.

57 "Me parece que escribir es por naturaleza casi la oposición de la acción. De ahí uno de los motivos esenciales por los que no estoy conforme con mi vida. Una vida signada por la escritura me parece casi una vida perdida. Yo, en cambio, hubiera preferido disolverme en la acción. Ésa es la manera que permite a un hombre desarrollar sus posibilidades y elaborar el destino que le corresponde". Véase la "Entrevista" hecha al escritor por Héber Cardoso y publicada en Hispamérica 1 1-12 (Ottawa, 1975) 50, citada en Gladys Vila Barnes 85.
} 
precisamente en "El sonámbulo" se expresa lo mismo cuando el padre le dice a Carmona todavía mozo que la substancia del hombre son sus acciones y que sólo éstas le permiten no perderese en laberintos (36).

Lo dicho quizá permite penetrar mejor en las motivaciones del escritor al relatar, en $E l$ fiscal, una historia en que el protagonista "actúa" tanto en el presente como en el pasado dirigiéndose, respectivamente, contra Stroessner y en favor de Francisco Solano López. Podemos llegar hasta interpretarlo todo como expresión de cierto sentido de culpa de Roa Bastos, por no haber podido o sabido luchar por su patria a través de la acción. Félix Moral es un fiscal que se ha autonombrado para cumplir con la tarea extraordinaria de matar al dictador, pero que fracasa, como ya fracasaron en su contexto el fiscal de sangre Fidel Maíz, el fiscal general José Segundo Decoud, etc. La historia de Félix Moral, quien fue víctima de la "alucinación en marcha de la historia" (El fiscal 352), quizá podría también interpretarse en cierta medida - pero no me oculto que aquí caigo en un excesivo y resbaladizo psicologismo - como el venir abajo, al término de su vida, de muchas de las ilusiones del mismo Roa Bastos. ${ }^{58}$ De ahí la necesidad de compensar eso: pues, de un lado, la afectada exalatación del amor sentimental y físico por la última mujer $\mathrm{y}$, del otro, el robustecimiento de la positiva revisitación de un héroe controvertido y ya mítico.

Volvamos a un terreno más sólido. Por ser aquí innecesarias, no me detengo sobre las implicaciones más acentuadamente políticas que la fascinación ejercida por el mariscal sobre Roa Bastos podría proporcionar a los lectores. Es suficiente observar que Francisco Solano López, como ya el doctor Francia, si comparado con los siguientes jefes de gobierno paraguayos termina por ser valorizado, por su temple y por su actitud nacionalista. ${ }^{59} \mathrm{Al}$ contrario de como se justificó a propósito de Yo el Supremo, cuando dijo que el nombre de Gaspar Rodríguez de Francia nunca aparece en la novela y que no hay que identificar al Dictador protagonista de la ficción con el Doctor Francia histórico, ${ }^{60}$ ahora, en los más explícitos textos que hablan con nombre y apellido del mariscal, el escritor no puede escapar de una confrontación histórico-política evidente. Si se quiere, pues, la ambigüedad sobre él es aun mayor que aquélla realizada con el enfoque del Dictador perpetuo.

\footnotetext{
${ }^{58}$ Observaciones semejantes podría sugerir aun Contravida: reservo para otra ocasión el examen de la última novela del escritor.

${ }^{59}$ Por lo que se refiere a la comparación, es revelador un juicio pronunciado por Félix Moral sobre Stroessner: "Un hombre infinitamente mediocre, convertido en amo absoluto de un país que ha tenido caudillos de un temple extraordinario". (El fiscal 215). Por su parte, el nacionalismo antimperialista, compartido en América Latina por la izquierda y la derecha radicales, está bien expresado a través de una serie de frases anacrónicas que el mariscal pronuncia en la novela (por ejemplo, a la página 267 habla de "pacto neocolonial"); se refleja en el empleo, de parte de Moral, de "vendepatrias" (296), una de las palabras mágicas del revisionismo historiográfico hispanoamericano; se manifiesta en poner junto a Francisco Solano López, como emblemáticos héroes antes victoriosos y luego derrotados, a Simón Bolívar, a José Martí y al Che Guevara (170).

${ }^{60}$ Por ejemplo en "Algunos núcleos generadores de un texto narrativo", Roa Bastos deja bien sentado que "El Supremo novelesco o de la novela" y "El Supremo Dictador de la historia real" son "dos entidades específicamente diferentes y por momentos antagónicas" (180).
} 
Roa Bastos, pues, confirma su intención revisionista de la historia del país: en este sentido El fiscal tiene derecho a formar parte de la "Trilogía paraguaya", junto con las dos más antiguas, y mejores, novelas.

\section{Bibliografía}

Albònico, "Un rompecabezas político y literario paraguayo: el Doctor Francia". Literatura y política en América Latina. Actas del Congreso. Salerno 6-8 de mayo de 1993. Rafael Di Prisco-Antonio Scocozza (coordinadores). Caracas: Ediciones La Casa de Bello, 1995. 111-151.

Barrett, Rafael. El dolor paraguayo. Caracas: Biblioteca Ayacucho, 1978.

Calzada, Rafael. Rasgos biográficos de José Segundo Decoud. Homenaje en el $4^{\circ}$ aniversario de su fallecimiento. 4 de marzo de 1909. Buenos Aires: s.e., 1913.

Enciclopedia Universal Ilustrada Europeo-Americana. Madrid-Bilbao-Barcelona: EspasaCalpe, s.f.

Ferrer Agüero, Luis María. El universo narrativo de Augusto Roa Bastos. Madrid: Facultad de Filología, Universidad Complutense de Madrid, 1981 (tesis doctoral).

"Hacia el pluralismo democrático en Paraguay". Cuadernos Hispanoamericanos 408 (Madrid, junio 1984).

Leenhardt, Jacques (ed.) Littérature Latino-américaine d'aujourd'hui. París: Union Générale d'Editions, 1980.

López, Cándido. Imágenes de la guerra del Paraguay, con un texto, El Sonámbulo, de Augusto Roa Bastos. Parma: Franco Maria Ricci, 1984.

Immagini della guerra del Paraguay con un testo di Augusto Roa Bastos, Introduzione critica di Marta Dujovne. Testi annessi di Antonio Cándido e Raquel de Queiroz. Franco Maria Ricci, ed. Parma, 1976.

Marini Palmieri, Enrique. "Roa Bastos: Yo el Supremo". Paul Verdevoye (coordinateur), "Caudillos", "caciques" et dictateurs dans le roman hispano-américain. París: Editions Hispaniques, 1978.

Moreno, Fernando. "Para una nueva lectura de Hijo de hombre". Anthropos 115 (Barcelona, 1990): 54-58.

O'Leary, Juan Emiliano. El mariscal Solano López. Madrid: Imprenta de F. Moliner, 1925. Roa Bastos, Augusto. El fiscal. Madrid: Alfaguara Hispánica, 1993.

Hijo de hombre. Madrid: Alfaguara, 1992.

Yo El Supremo. Milagros Ezquerro, ed. Madrid: Cátedra, 1983.

"El sonámbulo". París: Belfont, 1982 (edición francesa). Asunción: ElLector, 1983 (edición castellana).

Antología personal. México: Ed. Nueva Imagen, 1980.

Yo El Supremo. Buenos Aires: Siglo XXI, 1974.

El trueno entre las hojas. Buenos Aires: Losada, 1961.

Hijo de hombre. Buenos Aires: Losada, 1960.

Rodríguez Alcalá, Hugo. "Augusto Roa Bastos y el bilingüismo paraguayo". Cuadernos Americanos (México, enero-febrero 1976): 198-207. 
“Jorge Luis Borges en 'La excavación' de Augusto Roa Bastos”. Helmy F. Giacoman, ed. Homenaje a Augusto Roa Bastos. Variaciones interpretativas en torno a su obra. New York-Madrid: Anaya, 1973. 221-236.

Ruffinelli, Jorge. "Roa Bastos: el origen de una gran novela". Saúl Sosnowski, comp. Augusto Roa Bastos y la producción cultural americana. Buenos Aires: Ediciones de la Flor, 1986. 139-149.

La tiranía en el Paraguay; sus causas, caracteres y resultados; colección de artículos publicados en "El Cívico». Asunción: Tipografía de "El País", 1903.

Velázquez, Rafael Eladio. Breve historia de la cultura en el Paraguay. Asunción: Centro de Publicaciones de la Universidad Católica, 1982.

Vila Barnes, Gladys. Significado y coherencia del universo narrativo de Augusto Roa Bastos. Madrid: Orígenes, 1984. 